\title{
POSTJUGOSŁOWIAŃSKI TEATR PAMIĘCI W PROJEKTACH WIZUALNYCH BÁLINTA SZOMBATHYEGO I JASMINY CIBIC ${ }^{1}$
}

\author{
MAGDALENA BOGUSŁAWSKA
}

\begin{abstract}
Post-Yugoslavic theatre of memory in the visual projects of Bálint Szombathy and Jasmina Cibic.
The starting point of my considerations is the category of the theatre of memory, taken from Francis Yates' book Art of memory. The category was applied in the book in relation to ancient traditions and mnemonic techniques. In the article I attempt to reinterpret this category and apply it in the description of the contemporary practices of commemorating and reminding of the Socialist Yugoslavia's experience in space and through space. I am interested in the artistic activities of contemporary visual creators who in their works deal with the subject of SFRY. Referring to the example of the works of the artists belonging to different generations, I discuss two trends seen in the reception of this historical experience. Metonymic approach (Szombathy) is based on problematizing one's own biographical experience as a part of the Great History, while the metaphorical recognition (Cibic) means a search for universal content in what is historical and local.
\end{abstract}

Autor: Magdalena Bogusławska, Instytut Slawistyki Zachodniej i Południowej Uniwersytetu Warszawskiego, ul. Krakowskie Przedmieście 26/28, 00-927 Warszawa, m.boguslawska@uw.edu.pl

Slowa kluczowe: sztuki wizualne, pamięć, socjalistyczna Jugosławia, kultura władzy, polityczność, architektura, podmiotowość

Keywords: visual arts, memory, socialist Yugoslavia, culture of power, political character, architecture, subjectivity

Balcanica Posnaniensia. Acta et studia, XXII/2, Poznań 2015, Wydawnictwo Instytutu Historii UAM, pp. 187-200, ISBN 978-83-63047-88-7, ISSN 0239-4278. Polish text with a summary in English.

\section{O ZASTOSOWANIACH POJĘCIA TEATR PAMIĘCI}

Teatr pamięci to termin pojemny, który w toku historii zyskiwał rozmaite wykładnie. Jego źródło możemy, tropem książki Frances Yates Sztuka pamięci, wywieść ze starożytnej sztuki retoryki. Praktykujący ją mówcy posługiwali się architekturą pamięci, czyli specjalnymi, wyobrażeniowymi konstrukcjami przestrzennymi, w których określonym loci na zasadzie asocjacyjności przyporządkowane były określone zapamiętane treści. Chcąc je odtworzyć i ułożyć w logiczne sekwencje, orator/retor przemieszczał się myślą po takim (wyimaginowanym) gmachu i wywoływał z pamięci znaczenia kodowane przez kolejne wyobrażone miejsca. Z czasem sztuka pa-

${ }^{1}$ Artykuł został opracowany w ramach projektu badawczego nr 2012/05/B/HS2/04097 pt. Josip Broz Tito - od spektaklu władzy do teatru pamięci, finansowanego ze środków Narodowego Centrum Nauki. 
mięci z mnemotechniki urosła do rangi systemu i stała się narzędziem epistemologii totalnej, której celem było poznanie świata w jego pełni, odkrycie za pomocą misternej konstrukcji przestrzenno-symbolicznej związków (często utajonych, hermetycznych) zachodzących pomiędzy zjawiskami rzeczywistości. Stąd też w renesansowych systemach mnemonicznych, w tym przede wszystkim w doniosłym, choć nigdy nie ukończonym, szesnastowiecznym projekcie Giulia Camilla, teatr pamięci miał stanowić przestrzeń syntetycznego uobecniania i zarazem reprezentowania wyobrażeń archetypowych, miał być ekspresją porządku „wieczystej prawdy”, dokonującą się za pomocą odzwierciedlonych w pamięci elementów świata zmysłowego ${ }^{2}$. Twórca ten, nawiązując w swym dziele do tradycji hermetycznych i kabalistycznych, chciał, by widz poprzez lustrację wyobrażeń mnemonicznych mógł „odczytać całą zawartość Wszechświata”, albowiem to właśnie opanowanie kosmicznego porządku rzeczy było celem nowożytnej ars memorativa.

Paradygmatyczny dla rozumienia fenomenu teatru pamięci, mnemoniczny system Camilla, oparty na wizji architektonicznego, czyli zmysłowego unaoczniania i uobecniania pamięci, stanowi jeden z głównych układów odniesienia dla pojęcia architektury pamięci, którą rządzi reguła odpowiedniości miejsca (w sensie fizycznym) i wyobrażenia. Treści imaginatywne zostają powierzone przestrzennie rozmieszczonym figurom (znakom), dzięki którym teatry pamięci jako budowle funkcjonują niczym trójwymiarowa mapa, która ma pobudzać umysł, wprawiać w ruch pamięć, strukturować ją, a także estetyzować.

Ideę przestrzennej, a ściślej rzecz ujmując - wizualnej inscenizacji treści imaginacyjnych podjęly na nowo w XX wieku atlasy mnemiczne. Najbardziej reprezentacyjnym dla tej koncepcji jest atlas Mnemosyne Aby'ego Warburga, w którym pamięć została potraktowana jako doświadczalna konkretność, w toku dziejów zapisana w obrazach. Kapitalne, choć nigdy nie ukończone, dzieło niemieckiego historyka sztuki uzmysławia rolę wyobraźni i percepcji artystycznej - opartej na myśleniu nielinearnym, asocjacyjnym, wrażeniowym i posługującej się procedurą montażu - w procesie kształtowania i wyrażania pamięci kulturowej. Wskazuje także dowodnie na występujące między tymi porządkami - kreatywno-imaginatywnym i pamięciowym - podobieństwo.

Współczesne propozycje aktualizacji kategorii teatru pamięci wiązać należy z popularnością badań pamięciologicznych, a zwłaszcza z podnoszoną na nowo kwestią ontologii pamięci - a więc z pytaniem, czy współcześnie pozostaje ona domeną czasu, czy może osadzona jest w przestrzeni? Współczesna ars memoriae dowodzi potrzeby materialnych zakotwiczeń pamięci - w zapisie, w przestrzeni, w przedmiocie. To, co z dziedzictwa dawnych mistrzów tej sztuki wydaje się dziś kluczowe, to potrzeba ustanowienia relacji pomiędzy wyobrażeniem i jego materialną reprezentacją bądź emblematem, czyli między porządkiem rzeczy a porządkiem idei. W dzisiejszym świecie wszechobecna wydaje się, motywowana procesami cywilizacyjnymi

\footnotetext{
${ }^{2}$ F. A. Yates, Sztuka pamięci, tłum. W. Radwański, Warszawa 1977, s. 144, 163.

${ }^{3}$ Tamże, s. 162.
} 
i głębokimi przemianami form komunikacji, praktyka unaoczniania i uprzestrzennienia przeszłości - tworzenia miejsc stanowiących jej nośnik (pomniki, muzea, miejsca upamiętnienia). Jest ona pochodną koncepcji pamięci jako takiego działania umysłu, takiej aktywności wyobraźni, która prowadzi do przekroczenia czy też zawieszenia (a nawet zniesienia) granicy pomiędzy tym, co minione, a teraźniejszością. Owo transtemporalne podejście narusza zatem tradycyjną, linearną percepcję czasu, rekonfiguruje doświadczenie czasowości (a zwłaszcza poczucie ciągłości) poprzez synchronizację przeszłości i teraźniejszości, ale też poprzez akomodację do aktualnych warunków oraz instrumentalizację tego, co historyczne.

Żywa obecność przeszłości w świadomości społecznej i przestrzeni publicznej może przybierać formę obsesji przeszłością, może oznaczać absolutyzację autorytetu historii. Wydaje się to szczególne niebezpieczne wówczas, gdy przeszłość pozostaje uwięziona w micie, a współczesność traktowana jest jako jego epifania; kiedy historia poddana logice ideologii staje się polityką i narzędziem symbolicznej przemocy. Mechanizm ten - w przypadku interesującego nas obszaru pojugosłowiańskiego nazywany retradycjonalizacją - doskonale obrazują następujące słowa emigracyjnego serbskiego pisarza o żydowskich korzeniach, Davida Albahariego:

Przeszłość, życie w przeszłości proponuje się jako substytut życia w teraźniejszości, [...] czyli wymaga się od życia, by było ciągłym dreptaniem w miejscu, nieustannym odgrywaniem przeszłości, które staje się celem samym w sobie ${ }^{4}$.

\section{JĘZYK SZTUKI - JĘZYK PAMIĘCI}

Doświadczenie nadmiaru, „,nadprodukcji” czy też inflacji historii przy jednoczesnym poczuciu dezawuacji i niedoboru sensu jest dominującym motywem sztuki krytycznej twórców wizualnych pochodzących z krajów, które w drugiej połowie $\mathrm{XX}$ wieku współtworzyły socjalistyczną Jugosławię. Reprezentują oni różne generacje, a także różne przynależności etniczne, narodowe i państwowe. To, co ich łączy, to potrzeba przywołania w pamięci fenomenu (niemożliwej już) wielonarodowej wspólnoty i będącej jej formą struktury symbolicznej, ściśle powiązanej z ideologią federacyjnego państwa. Zbliża ich do siebie także próba przepracowania i zrozumienia traumy dramatycznego końca tego projektu. Do tego nurtu tematycznego, stanowiącego differentia specifica współczesnej sztuki krajów dawnej Jugosławii, a także w istotny sposób określającego jej tożsamość, można zaliczyć prace wielu artystów. Tych, którzy ukształtowali swój warsztat, styl, a przede wszystkim sposób rozumienia (zadań) sztuki w czasach socjalistycznej Jugosławii, a więc m.in. Mladena Stilinovicia, Sanji Iveković, Tomislava Gotovaca, Dragana Srdicia, oraz tych, którzy pierwsze twórcze doświadczenia zdobywali w warunkach kryzysu, jaki nastąpił w związku z rozpadem

${ }^{4}$ D. Albahari, Mamidto, tłum. D. J. Ćirlić, Warszawa 2008, s. 134. 
federacji, do tej grupy należą np. Chorwaci Igor Grubić, Nemanja Cijanović czy Igor Bošnjak z Bośni i Hercegowiny.

Jakkolwiek artyści obu pokoleń odnoszą się do przeszłości, w popularnym przekazie sygnowanej sugestywnym, nostalgicznym mianem Ju-Atlantydy bądź Titonika, to jednak wyraźnie można dostrzec, iż mamy tu do czynienia z różnymi sposobami konceptualizacji tematu i odmiennymi perspektywami interpretacyjnymi. Dobrze tę różnorodność pozwoli ukazać konfrontacja dwu wybranych przedsięwzięć: retrospektywnej wystawy autorskiej Bili smo heroi / Hösök voltunk (Byliśmy bohaterami) Bálinta Szombathy’ego (1950) - urodzonego w socjalistycznej Jugosławii węgierskiego artysty, od lat 70. silnie związanego z tamtejszą neoawangardową sceną artystyczną, oraz wideo-instalacji Tear Down and Rebuild (Zburzyć i odbudować) słoweńskiej artystki Jasminy Cibic (1979), aktualnie mieszkającej i działającej w Londynie.

Do (metaforycznego) zastosowania kategorii teatru pamięci w odniesieniu do prac będących przedmiotem niniejszego omówienia upoważnia tryb ekspozycji prac artystycznych, oparty na zasadach instalacji przestrzennej. Ulokowane w galerii dzieło nie tylko zostaje podporządkowane regułom pomieszczenia, jego kształtowi, historii i energii, lecz także wchodzi w z nim interakcję, wydobywa dodatkowe wartości proksemiczne, a tym samym inicjuje proces semiozy, otwiera nowe pola interpretacji, aktywizuje i dynamizuje pracę pamięci kulturowej, która jest tworzywem działania artysty (jak również kuratora). Prowadzi to do rozbicia tradycyjnej monologicznie ustrukturowanej narracji wystawowej, do jej zdynamizowania i zdialogizowania, by uczynić ją nośnym układem percepcyjnym. W obu interesujących nas przypadkach mamy do czynienia z taką aranżacją przestrzeni galeryjnej, dzięki której ta staje się swoistą mnemoniczną machiną. Nie tylko inscenizuje spojrzenie odbiorcy, lecz performuje jego zachowania i emocje, a przede wszystkim in statu nascendi tworzy/animuje pamięć ujmowaną jako domena porządku imaginacyjnego.

Prezentacja prac Bálinta Szombathyego została zorganizowana w 2014 roku przez dwie galerie „Vinko Perčić” i „Likovni susret“ w położonej przy granicy serbsko-węgierskiej Suboticy, z którą artysta związany jest od początku swej twórczej drogi. Tytuł retrospektywy nie tylko zapowiada odniesienie do przeszłości, lecz także przywołuje etos heroizmu, który w świadomości społecznej i mentalności tego regionu Europy stanowi on wartość kluczową, tworzy oś tzw. epickiego modelu kultury, w toku dziejów wyniesionego do rangi fundamentu lokalnej tradycji politycznej. Dla artysty inkarnacją idei bohaterstwa jest socjalistyczna Jugosławia, na czas istnienia której przypadły jego dzieciństwo i młodość. Po drugiej wojnie światowej heroizm Titowskich oddziałów partyzanckich, kontynuowany w warunkach pokojowych przez budowniczych nowego państwa jugosłowiańskiego (czyli „masy robotniczochłopskie"), stał się podstawą założycielskiego mitu, legitymizującego komunistyczne rządy, był dominującą treścią publicznego przekazu, wiodącym hasłem propagandowej retoryki. Bohaterska postawa, której pouczających przykładów dostarczały losy uczestników antyfaszystowskiego frontu, stała się głównym przesłaniem parenezy skierowanej do pionierów i socjalistycznej młodzieży. 
Tę zinstrumentalizowaną propagandowo paralelność doskonale obrazuje puentujący całość kolaż Tito i ja / Tito és én. Złożony z dwu starych fotografii wklejonych do rodzinnego albumu przedstawia jugosłowiańskiego prezydenta, Josipa Broza Titę w marszałkowskim mundurze, z kolekcją orderów na piersi, i Bálinta Szombathyego jako chłopca w wieku szkolnym. Dodatkowo, by zachować nie tylko formalną, ale też semantyczną symetrię, obok zdjęcia artysta poprzypinał znaczki, u góry pod sygnaturą Tity umieścił te z wygrawerowanymi pałkami sztafetowymi, u dołu te, które w dzieciństwie zdobywał jako honorowy dawca krwi. Skonfrontował w ten sposób patos wielkiej historii i małe trofea pionierskiego heroizmu. $Z$ jednej strony ta gra, wykorzystująca na zasadzie metonimii ikoniczne reprezentacje makro- i mikrohistorii, ma dla twórcy wartość sentymentalną - ukazuje osobisty, a nawet intymny wymiar pamięci o socjalistycznej Jugosławii, z drugiej zaś Szombathy nadaje kolażowi wyraźnie krytyczną wymowę. Pionierstwo było bowiem w komunistycznym państwie sprawą edukacyjnego przymusu, a nie indywidualnego wyboru, było - co w autobiograficznym opowiadaniu Czerwona orkiestra sugestywnie ukazał Andrzej Mandalian $^{5}$ - formą nowoczesnego janczarstwa, triumfem kolektywizmu i synonimem poświęcenia $\mathrm{w}$ imię wspólnoty - poświęcenia motywowanego nie tyle świadomością, ile presją symboliczną, będącego więc rodzajem ujarzmienia indywiduum. Toteż tytuł swej wystawy Szombathy tłumaczy, przywołując nie piewców epickich cnót odrodzonych w postaci partyzanckiej waleczności, ponieważ ten nadzwyczaj łatwo stał się w Jugosławii pożywką nacjonalizmów i bratobójczej wojny, lecz parafrazując popularny song Boba Dylana, który śpiewa po prostu, że każdy może być bohaterem, codziennie, pokonując swoje słabości i ograniczenia.

Młoda sztuka lat 70. (a na te lata przypadł debiut Szombathyego), uprawiana przede wszystkim pod auspicjami ośrodków studenckich, była reakcją na tę indoktrynację, a dokładniej rzecz ujmując na fasadowość i ideologiczny pozór spektaklu władzy. Stanowiła wyraz niezgody na ograniczenia twórczej podmiotowości i aktywności, próbę ich uwolnienia spod wpływów doktryny politycznej, kolonizującej każdy obszar życia jednostki i społeczeństwa. Sztuka krytyczna tego okresu wytyczała również kierunki poszukiwań nowej formuły zaangażowania, która wbrew obowiązującym regułom, stanowiłaby alternatywę dla aktywności polegającej na apologii i afirmacji komunistycznego systemu. Młodzi twórcy jugosłowiańscy, rozczarowani spetryfikowaną akademicką praktyką i refleksją o sztuce, awangardowej, rewolucyjnej energii szukali na obrzeżach sceny artystycznej, w inspirowanej hasłami nowej lewicy zachodniej kontrkulturze. Właśnie o tym doświadczeniu artystycznym opowiadają zgromadzone na wystawie Bili smo heroi / Hösök voltunk dzieła Bálinta Szombathyego z tego okresu - kolaż Dekonstrukcija Jugoslavije / Jugoszlávia dekonstrukciója (Dekonstrukcja Jugosławii), instalacje zdjęcia dokumentujące performanse i akcje Lenin in Budapest, Bauhaus, Zastave / Zászlók (Flagi), a więc prace reprezentujące nomen omen heroiczny etap twórczości autora. $Z$ kolei powstałe w latach dziewięćdziesiątych instalacje Yugoslav Story, Dalekogled / Messzelátó (Lornetka)

\footnotetext{
${ }^{5}$ A. Mandalian, Czerwona orkiestra, Warszawa 1993 (2 wyd. 2009).
} 
czy Balkanski dialog / Balkáni diaógus (Bałkański dialog) odnoszą się bezpośrednio do rozpadu SFRJ i jego następstw.

Ekspozycję spaja, tworząca przestrzenny, ale i znaczeniowy wektor, instalacja $O d$ kolevke pa do groba / A bölcsötöl a sírig (Od kolebki aż po grób). Obiektem inicjalnym jest tu kołyska wraz z wiszącą ponad nią, na ścianie mapą byłej Jugosławii, na przeciwległym krańcu znajduje się katafalk, na którym leży na marach woskowa kukła przedstawiająca Josipa Broza Titę - jej oczy są otwarte. W wizualnej opowieści artysty o własnym doświadczeniu socjalistyczna Jugosławia sytuuje się gdzieś w pół drogi między historyczną realnością a iluzją, między ideą a wspomnieniem. Realizuje się tak w wymiarze indywidualnie przeżywanej codzienności, w pewnej nasyconej emocjami przestrzeni, jak i w postaci wielokulturowej wspólnoty, dynamicznego środowiska intelektualnego, platformy twórczego działania. Tito stanowi symboliczne centrum tego metageograficznego terytorium, stały i niezbywalny punkt odniesienia, istotny w interpretacji zarówno wielkiej historii narodów, państw, regionu, jak i w pojedynczej biografii tzw. zwykłego człowieka. Artysta poprzez fotografie i przedmioty animuje obecność charyzmatycznego przywódcy, który we współczesnej świadomości społecznej funkcjonuje na zasadach fantazmatu, silniej oddziałującego dziś (często nieświadomie) na kulturę władzy i jej społeczną percepcję niż aktualną polityczną rzeczywistość. Szombathyego interesuje Tito jako kreator wielkiej utopii, która po drugiej wojnie światowej w sferze politycznej, cywilizacyjnej i społecznej stanowiła prawdziwie twórczy impuls i z której lewicowym tonem - jako zwolennik sztuki krytycznej, zaangażowanej, polemicznej - się identyfikuje. Równocześnie niedomknięte oczy woskowego trupa sugerują pytanie będące motywem przewodnim wystawy Bili smo heroi / Hösök voltunk, a które wprost formułuje jej kurator, Nebojša Milenković: co uczynić z nadmiarem historii, co zrobić z jej reliktami, zwłaszcza wówczas gdy upłynął termin ich zdatności do użycia? ${ }^{6}$

Za sprawą semio-artystycznych operacji Szombathyego obiekty i znaki tworzące kod jugosłowiańskiego uniwersum symbolicznego zostają przetransponowane na język sztuki. I choć język ten czerpie wiele z estetyki (jugo)nostalgii, to również ją przewartościowuje. Artysta aranżuje galeryjną przestrzeń nawiązując do tradycyjnej stylistyki izb pamięci, eksploatuje antykwaryczną wartość zgromadzonych artefaktów - jugosłowiańskie pamiątki, Titowskie „dewocjonalia”, nostalgiczne objets trouvés, dziś często po prostu rupiecie i odpadki - przekształca w semiofory. Przełamuje afirmatywność muzealnych ekspozycji, przede wszystkim ingerując w materialną tkankę archiwalnych materiałów, naruszając ich integralność, dokonując przekształceń w ich ikonicznej, a co za tym idzie, także znaczeniowej strukturze. Twórcze interwencje rozsadzają jednoznaczność przesłania dokumentów, a tym samym relatywizują ocenę historycznego doświadczenia. Obnażają anachronizm, jakim skażone są próby odczytywania współczesności poprzez mechanicznie reprodukowane matryce

${ }^{6}$ Zob. N. Milenković, Višak istorije kao umetnički materijal, w: Bálint Szombathy, Bili smo herosi / Hösök voltunk [katalog wystawy], http://pl.scribd.com/doc/240135050/Balint-Szombathy-Bili-smoheroji-H\%C5\%91sok-voltunk-KATALOG [dostęp 22.09.2015]. 
historii, co prowadzi do redukcji rzeczywistości, niedostrzegania jej złożoności i odmienności, a przede wszystkim do wtłoczenia jej w zamknięty krąg mitu. Tego rodzaju regresywne myślenie, stawiając $\mathrm{w}$ centrum pokusę powrotu, stymuluje uczucie nostalgii. Pozostaje zarazem w jawnej sprzeczności z postawą nowoczesną, racjonalną, otwartą, nastawioną na zmianę i rozwój. Według diagnoz badaczy kultury Bałkanów, takich jak np. Ivan Čolović, Maria Todorowa, Latinka Perović, ten właśnie konflikt między „,ideologią zaścianka”, która swą polityczną rację legitymizuje zmitologizowaną wizją historii i kolektywnych tożsamości, a zdecydowanie mniej popularną postawą progresywistyczną, motywowaną przez imperatyw cywilizacyjnej (w tym także intelektualnej) modernizacji społeczeństwa, stanowi realne źródło kryzysu utrzymującego się od lat w regionie Bałkanów.

Jakkolwiek przesłanie retrospektywy Bálinta Szombathyego można umieścić w tym szerokim kontekście, to jednak z całą mocą należy podkreślić, iż pozostaje ona wypowiedzią autorską, indywidualną i - jak sądzę - na przekór gramatycznej formie tytułu utrzymaną w pierwszej osobie liczby pojedynczej. Milenković, powołując się na węgierskiego historyka sztuki, Lóránda Hegyiego, twierdzi, że omawiana wystawa, będąc konceptualną konstrukcją, czyli przemyślanym ustrukturowaniem wspomnień poprzez uporządkowanie artefaktów i przetworzenie w przestrzenną instalację wyraża charakterystyczną dla tej części Europy, która została naznaczona doświadczeniem komunizmu i jego bankructwa, potrzebę zrozumienia, a także zdefiniowania na nowo własnej tożsamości, wskazania czy też ustanowienia nowych układów odniesienia, nowych światopoglądowych koordynatów ${ }^{8}$.

\section{ARCHITEKTURA WŁADZY JAKO SCENA PAMIĘCI}

Pamięć jugosłowiańskiego „socwiecza” zdaje się rezonować nieco inaczej w pracach młodszego pokolenia twórców, związanych swym pochodzeniem i biografią z nieistniejącym już dziś państwem. Choć także w ich pracach podstawowym instrumentarium nawiązań do minionej epoki stają się jej znaki graficzne, jej style, jej ikonosfera, to jednak zdecydowanie mniej tu przywiązania do rekwizytów - śladów przeszłości, rzeczy, pamiątek (z więc materialnych nośników emocji), większą natomiast rolę zdaje się odgrywać obraz, imaginacyjny konstrukt bądź kreacja wizualnej opowieści. Innymi słowy, w dziełach młodszej generacji twórców dostrzec możemy przesunięcie od metonimii jako zasady twórczej w stronę metafory. Taki tryb artystycznego działania odpowiada współczesnemu rozumieniu pamięci, zgodnie z którym nie tylko bezpośrednio odciśnięty w umyśle ślad wywołuje wspomnienia, lecz może je również wygenerować zewnętrzne słowo, dźwięk, obraz.

7 Określenie „ideologia zaścianka” (serb., chorw. „ideologija palanke”) nawiązuje do kapitalnego dzieła Radomira Konstantinovicia z zakresu filozofii kultury pt. Filosofija palanke (1969), w którym autor analizuje fenomen prowincjonalności.

${ }^{8}$ N. Milenković, Višak istorije kao umetnički materijal, op.cit. 
Do materii twórczych transpozycji i transfiguracji autorzy ci podchodzą bez sentymentu/sentymentalizmu, pochylają się nad nią raczej - by tak rzec $-\mathrm{z}$ analityczną racjonalnością, chcąc prześwietlić, przeniknąć język form i unaocznić jego kognitywny wymiar, dostrzec stojący za nim złożony wymiar przekonań, wierzeń, uprzedzeń. A ponieważ skondensowaną artykulacją doktryny ideologicznej jugosłowiańskiego państwa był specyficzny model władzy ucieleśniony w autorytarnych rządach Josipa Broza Tity, w dość oczywisty sposób również w przedsięwzięciach tych artystów staje się on dziś dominantą symboliczną w postjugosłowiańskim porządku pamięci jako postać charyzmatyczna, dobrze rozpoznawalna także poza kontekstem lokalnym. Twórcy młodszej generacji zdają się do tej recepcji wnosić nową jakość, choćby dlatego, że w ich spojrzeniu na przeszłość oraz jej głównego aktora mocno dochodzi do głosu ujęcie prospektywne, które włącza autorską refleksję nad historią w zdystansowany i krytyczny dyskurs dotyczący kondycji rzeczywistości społecznej i staje się impulsem dla projektów jej przemodelowania. Pozycja, z której wychodzą, można określić jako pozycję ,po kryzysie”.

Tendencję tę dobrze ilustruje wspomniana już wideoinstalacja Jasminy Cibic Tear Down and Rebuild, którą można uznać za artystyczne studium na temat architektury władzy i pamięci. Słoweńska artystka przywołuje obraz (wyobrażenie) socjalistycznej Jugosławii jako „gorący“, a więc łatwo rezonujący znaczeniowo kontekst dla rozważań na temat fenomenu władzy jako takiej i sposobów, w jakie jest ona stanowiona i wyrażana w przestrzeni i poprzez przestrzeń przede wszystkim za pomocą architektury reprezentacyjnych budynków państwowych instytucji oraz estetycznych aranżacji ich wnętrz. Cibic wybiera zatem formy ściśle podporządkowane ideologicznej i politycznej intencji, które w zamiarze swych twórców miały uczestniczyć w spektaklu władzy - miały służyć celebracji wielkości i siły panujących, ukazywać rodowód i cel ich rządów, a także eksponować moc stojącej u fundamentów tychże ideologicznej/mitycznej narracji. Osią wideoinstalacji Tear Down and Rebuild słoweńskiej autorki jest filmowa inscenizacja dyskusji o roli architektury - jej wielowymiarowej funkcjonalności, estetycznych walorach, aksjologicznym zapleczu i mitotwórczym potencjale. Znamienne znaczenie ma tu miejsce, w którym toczy się debata - to znajdujący się w Belgradzie niegdysiejszy Pałac Federacji - siedziba jugosłowiańskiej rady państwa (Savezno izvršno veće), w 2006 roku (po podziale Serbii i Czarnogóry) przemianowany na Pałac Serbii i przekazany do dyspozycji rządowi tego kraju.

Należy przypomnieć, że budynek ten powstał w czasach socjalistycznej Jugosławii jako element powojennego planu zagospodarowania i rozbudowy Nowego Belgradu, miał być sercem jego reprezentacyjnej części. Projekt ten realizowany z inspiracji i mocy ówczesnego przywódcy Josipa Broza Tity zakładał stworzenie nowoczesnej części stołecznego miasta, w której komunistyczne władze federacji chciały ulokować administracyjne centrum państwa, symbolicznie manifestując w ten sposób odcięcie się od monarchicznego dziedzictwa Serbii i określanych jako reakcyjne tradycji politycznych pierwszej Jugosławii, których materialne ślady pozostały w starej części Belgradu. Monumentalny modernistyczny budynek miał w pejzażu stolicy stano- 
wić kontrapunkt dla usytuowanej na przeciwległym brzegu Sawy, tureckiej twierdzy Kalemegdan. Z perspektywy nowych włodarzy państwa dominująca swą bryłą na stołecznym nabrzeżu zabytkowa cytadela stanowiła historyczny znak niegdysiejszej politycznej podległości. Nowej wizji nie odpowiadała również stara zabudowa miasta, w jego centrum stanowiąca refleks burżuazyjnych inklinacji przedwojennych elit ${ }^{9}$, a na obrzeżach przybierającą postać bałkańskiej palanki, zbyt mocno (jak na aspiracje nowych rządów) tchnącej zapóźnieniem i prowincjonalizmem. Wprawdzie Tito po wojnie skwapliwie przejął budynki królewskich siedzib i ulokował w nich federacyjne instytucje oraz rezydencje, to jednak Nowy Belgrad miał w jego zamyśle być manifestacją nie tylko politycznej, lecz również cywilizacyjnej zmiany, jaka nastąpiła po wojnie zyskującej w przekazie propagandowym status komunistycznej rewolucji. A zatem proklamacja budowy nowego miasta symbolicznie odsuwa przeszłość w zamkniętą sferę historii. Dla komunistycznych elit zaplanowana z wielkim rozmachem rozbudowa Nowego Belgradu, w tym także architektonicznej tkanki służącej symbolicznemu wzmocnieniu rangi państwowych instytucji, była materialną formą artykulacji powszechnie forsowanych treści ideologicznych (zwłaszcza ucieleśnieniem haseł o modernizacji), a tym samym stanowiła ważny czynnik legitymizacji rządów partii.

Budowę Pałacu Federacji, zaprojektowanego przez zagrzebski zespół Željka Potočnjaka, rozpoczęto w 1948 roku. Budynek został oddany do użytku dopiero w 1961 roku, tak by można było w nim ulokować pierwszy światowy Kongres Państw Niezaangażowanych ${ }^{10}$. Warto nadmienić, że uczestnictwo SFRJ w strukturach Ruchu Państw Niezaangażowanych stanowi dziś ważny element pamięci społecznej o jugosłowiańskim socjalizmie i w rozrachunku z przeszłością jest oceniane zasadniczo pozytywnie, bywa bowiem postrzegane jako miara politycznych aspiracji Jugosławii, która swą pozycję na arenie międzynarodowej w okresie zimnej wojny budowała, forsując hasła niezależności od komunistycznego bloku państw wschodnich z jednej i dystansu wobec kapitalistycznego Zachodu z drugiej strony. Z tego względu „niezaangażowanie" SFRJ, wsparte na zabiegach dyplomatycznych i kontaktach Tity z krajami tzw. Trzeciego Świata, stało się filarem zmitologizowanej narracji o jugosłowiańskiej „,trzeciej drodze". W jej ramach polityka zagraniczna Tity urastała do rangi pokojowej misji, a on sam zyskiwał rysy duchowego następcy Aleksandra Wielkiego, który zdobywa świat nie mieczem, a osobistą charyzmą i stylem (sic!) oraz dyplomatyczną maestrią ${ }^{11}$.

\footnotetext{
${ }^{9}$ Fakt ten komentuje szerzej np. Milovan Đilas w książce Druženje s Titom, Harrow, Middlesex 1980.

${ }^{10} \mathrm{~W}$ czasie jego trwania inicjator i patron wydarzenia, prezydent Josip Broz Tito w geście demiurga otworzył w pobliżu pałacu Park Pokoju, w którym każdy z przywódców goszczących wówczas w Belgradzie zasadził własnoręcznie drzewo-pomnik przyjaźni i pokoju. Dziś w zaniedbanym entourage'u platanowe aleje z szeregami umocowanych w ziemi tabliczek z nazwiskami w większości zapomnianych już polityków przypomina raczej opuszczony cmentarz niż park uosabiający obietnicę lepszego świata.

11 Temat ten omawiam szerzej w artykule: Egzotyczni przyjaciele Josipa Broza Tity, w: Komunistyczni bohaterowie, t. 1: Tradycja, kult, rytuał, red. M. Bogusławska, Z. Grębecka, E. Wróblewska-Trochimiuk, Warszawa - Kraków 2011.
} 
Można założyć, że to właśnie intensywne kontakty z postkolonialnymi krajami Azji i Afryki, przechodzącymi w latach powojennych głębokie procesy emancypacyjne i eksponujące autochtoniczne estetyki jako znak identyfikacji, obudziły w kreatorach wizerunku jugosłowiańskiego państwa potrzebę wyraźnego zaznaczenia jego wizualnej tożsamości, zrekonstruowania i wyeksponowania specyficznego dlań stylu za pomocą języka architektury, wzornictwa i form plastycznych. To zadanie miał spełniać powołany do celów reprezentacyjnych Pałac Federacji, który później, w toku historii wbrew tym szczytnym intencjom odegrał rolę świadka i niemego uczestnika upadku federacji (to tu podejmowano kolejne decyzje sankcjonujące jej demontaż). „Zamrożony” do dziś dnia w niemal niezmienionym kształcie stał się ikoną jugosłowiańskiej utopii, jej wzniosłości, kreacyjnych aspiracji i snów o potędze.

Jasmina Cibic nie bez powodu sytuuje dialog o architekturze władzy właśnie w jego wnętrzach. $Z$ rozmysłem eksploatuje teatralny potencjał modernistycznej budowli, którą inny artysta, serbski fotograf, Dušan Đorđević z uwagi na zakonserwowany wygląd i wystrój nazwał „kapsułą czasu”, nawiązując do dziecięcej zabawy, która polega na tym, że w metalowym pudełku zamyka się różne przedmioty, a następnie zakopuje, by po latach odnaleźć je i dzięki temu na powrót dotknąć przeszłości $^{12}$. Cibic inscenizuje swą dramę w stylowych, od lat niezmienionych scenografiach przestronnych gabinetów, konferencyjnych sal i rozległych korytarzy. Pomieszczenia te urządzone z niezwykłym rozmachem i przepychem stanowią kwintesencję ówczesnej estetyki, są najpełniejszym ucieleśnieniem jej elitarnego, reprezentacyjnego modelu. Barwne tkaniny, dywany z malarskimi motywami, wymyślne tapicerki foteli i kanap, meble o charakterystycznych kształtach, ściany wykładane różnokolorowymi płytami marmurowymi lub zdobione fantastycznymi reliefami i gobelinami, gigantyczne żyrandole tworzą imponującą oryginalną designerską kompozycję, znieruchomiałą, pokrytą patyną czasu.

W pracy artystki budowla w swej anachroniczności została potraktowana po pierwsze jako ewokacja powojennych wyobrażeń o nowoczesności oraz wiary w postęp i przyszłość, po drugie zaś forma wpisująca się w kompleks lokalnych tradycji plastycznych ekstensji władzy. Do ekskluzywnej dekoracji pałacowych pomieszczeń wykorzystano dzieła sztuki reprezentatywne dla poszczególnych republik i autonomicznych regionów Jugosławii, które doskonale nadawały się do tego, by współtworzyć ikonografię siły i prestiż. Możemy tu zobaczyć wykonane techniką fresku Let u kosmos (Lot w kosmos) Petara Lubardy czy Putevi Srbije (Drogi Serbii) Lazara Vujakliji, monumentalne mozaiki Stvaranje Jugoslavije (Stwarzanie Jugosławii) Mladena Srbinovicia i Sutjeskę Marija Pregelji, rzeźbiarskie podobizny Mihaila Pupina i Nikoli Tesli dłuta Drinki Radovanović, a także prace malarskie Milana Konjovicia, Stojana Aralicy, Risty Cvijovicia, wyniesione do rangi kanonicznych dzieł jugosłowiańskiej kultury. Pod względem zgromadzonych zbiorów sztuki obiekt przypomina więc narodową galerię, w której ekspozycja dzieł została podporządkowana wizji jed-

12 Dušan Đorđević uczynił Pałac Federacji tematem cyklu artystycznych fotografii Vremenska kapsula / SIV (2013). 
ności, dokonującej się poprzez połączenie mocą państwa wielu kulturowych podmiotów. Równocześnie monumentalne malowidła naścienne i mozaiki, mające zakorzeniać stylistykę wystroju obiektu w lokalnych, regionalnych i narodowych tradycjach, przywodzą na myśl bogato zdobione, zabytkowe świątynie - fundacje średniowiecznych władców serbskich, wznoszone z zamysłem stanowienia, wyrażania i podtrzymywania politycznej mocy władcy-budowniczego. Belgradzki pałac, choć w odróżnieniu od zorientowanych wertykalnie brył dawnych chramów płaski, rozbudowany horyzontalnie, tak samo jak one jest wizualnym zapisem ideologii państwa, architektonicznym kostiumem idei politycznej. Podobnie jak w przypadku historycznych cerkwi-pomników wyrafinowana estetyzacja i nagromadzenie obiektów sztuki okazuje się funkcją uwznioślenia tego, co jednostkowe, historyczne, przemijalne. Służy temu, by rozgrywający się na scenie historii spektakl władzy można było wpisać w nadrzędny rejestr symboliczno-ideowy, odnieść do wymiaru ponadczasowych wartości.

Pałac Federacji, budowany z myślą o tym, by spełniał funkcję sceny politycznych wydarzeń (rozgrywanych w obecności i z udziałem dostojnych zagranicznych gości), $\mathrm{w}$ filmie słoweńskiej artystki potraktowany na zasadzie ready made staje się scenerią rozważań o związkach sztuki i władzy. Zaczerpnięte z różnych źródeł wypowiedzi polityków, architektów, teoretyków na temat społecznego bytu, ideologicznej instrumentalizacji, ale też estetycznego znaczenia architektury, Cibic rozpisuje $\mathrm{w}$ formie dialogu, który w opustoszałych hieratycznych wnętrzach toczą między sobą cztery aktorki przedstawiające cztery wcielenia Matki Ojczyzny: Pragmatyczkę, Konserwatorkę, Artystkę-architektkę i Kreatorkę Tożsamości Narodowej. Kolejne sekwencje wypowiedzi puentuje chór. Kolaż cytatów z wypowiedzi politycznych przywódców, takich jak: Margaret Thatcher, Adolf Hitler, Benito Mussolini, Nikita Chruszczow, Tony Blair, Josip Broz Tito, a także architektów Paula Schultze-Naumburga, Ernesta Weissmana i wielu innych znanych postaci, jest owocem wnikliwych, archiwalnych studiów nad tematem, prowadzonych przez słoweńską artystkę. Cibic konfrontuje rozmaite przemyślenia o architekturze i przestrzeniach władzy, formułowane z perspektywy różnych systemów, racji oraz interesów. Niczym antyczny dramat (tę asocjację sugeruje obecność chóru) dotyczy odwiecznego konfliktu politycznych idei, socjalnie zorientowanego pragmatyzmu i estetycznych wartości. Dynamiczny splot tych uwarunkowań definiuje porządek, tożsamość i wygląd publicznych przestrzeni, decyduje o jakości toczącego się w nich życia, a także określa kształt i trwałość pamięci historycznej i kulturowej.

Kontekstem dla filmowego zapisu dysputy artystka uczyniła przemyślaną aranżację przestrzeni ekspozycyjnej, w której jest on prezentowany. Droga do szczelnie odgrodzonego ciężką kotarą pomieszczenia, gdzie odbywa się projekcja, prowadzi przez salę, której ściany zostały wytapetowane kompozycją czarnobiałych, panoramicznych fotografii krajobrazów z różnych części świata - Europy, Afryki, Azji. Autorka instalacji sugeruje jednak, że otaczający gościa galerii krajobraz - ukazujący malownicze wzgórza, dziewiczą i egzotyczną roślinność, otwartą przestrzeń - nie jest niewinny. Dowiadujemy się bowiem z autorskiego komentarza, że wykorzystane w instalacji zdjęcia pochodzą z archiwum Muzeum Historii Jugosławii, a zostały wy- 
konane podczas licznych wypraw dyplomatycznych Josipa Broza Tity, służących budowaniu jugosłowiańskiej ,polityki niezaangażowania”, a także międzynarodowego prestiżu socjalistycznej Jugosławii. I jakkolwiek obrazy te po prostu dokumentowały piękno widoków napotkanych w podróży, to zarazem były wykorzystywane w kształtowaniu wizerunku jugosłowiańskiego przywódcy, ugruntowywały kult jego osoby, innymi słowy - wspierały propagandowy przekaz. Operując strategią identyfikacji z super-bohaterem (egzotyczny pejzaż przekształcał dyplomatyczną rutynę w przygodę), miały budować autorytet i legitymizować imperialne aspiracje Marszałka ${ }^{13}$ oraz wzmacniać wśród Jugosłowian przekonanie o wielkości i stabilności państwa, a także ugruntowywać poczucie odrębności od krajów od bloku państw satelickich ZSRR, oddzielonych żelazną kurtyną od Zachodu. W ten sposób zwykła plenerowa, podróżna (można by rzec - turystyczna) fotografia zasilała wizualny język ideologii i dominacji. Ową niejednoznaczność specyficzną dla pejzażu władzy sygnalizują w instalacji słoweńskiej artystki fragmenty z wypowiedzi polityków i architektów np. Faith without works is dead, Fight the formalism, Strenuously serch for a new form itp., wymalowane złotą farbą na białych pasach-wstęgach wkomponowanych w różne części fototapety (w przypadku belgradzkiej odsłony instalacji napisy te zostały wykonane podczas performansu, który towarzyszył otwarciu wystawy).

Wystawa-instalacja Jasminy Cibic realizuje założenia sztuki site-specific - uruchamia aurę, a przede wszystkim semantyczny potencjał miejsca, w którym został zrealizowany film, a także zakotwicza artystyczny przekaz w utrwalonym społecznie/kulturowo wyobrażeniu o przeszłości ściśle związanym z tą przestrzenią. Oddziaływanie pracy Tear Down and Rebuild opiera się także na takim przekształceniu zastanej przestrzeni ekspozycyjnej, które inicjuje interaktywne otwarcie na otoczenie traktowane jako osobny semantyczny kontekst (w Belgradzie instalację prezentowała Galeria Muzeum Sztuki Współczesnej, usytuowana w pobliżu twierdzy Kalemegdan, będącej, o czym już nadmieniałam, historycznym znakiem (osmańskiej) kultury władzy i dominacji). W ten sposób artystka uzyskała dynamiczną konstrukcję polegającą na wprowadzaniu odbiorcy w kolejne odsłony instalacji. Zabieg ten przypomina gest Velasqueza, który w Pannach $d$ worskich niejako zaprasza widza do stopniowego wchodzenia w głąb obrazu i odkrywania różnych poziomów ikonograficznej narracji, pozbawiając ją tym samym jednoznaczności.

\section{HOMMAGE À SFRJ}

Analiza aktualnych praktyk artystycznych, przynależnych do postjugosłowiańskiego obszaru kulturowego ukazuje istnienie różnych tendencji w percepcji socjalistycznej przeszłości byłej federacji, przy czym zauważane odmienności należy wiązać

${ }^{13}$ Media akcentowały rolę lidera, którą Tito odgrywał w Ruchu Państw Niezaangażowanych, a tym samym przekonywały o ponadlokalnym zasięgu jego politycznego oddziaływania. 
ze zjawiskiem zmiany pokoleniowej. Dla twórców, którzy rozpoczynali swą twórczość na przełomie lat 60. i 70., zasadniczym układem odniesienia w interpretacji fenomenu SFRJ pozostaje konkretne, indywidualne doświadczenie, własna biografia ujmowana nie tylko na poziomie egzystencjalnym, ale przede wszystkim w wymiarze działań twórczych, konstytuujących tożsamość autora jako artysty. W tym wypadku, jak pokazuje przykład Bálinta Szombathyego, w centrum twórczych działań i refleksji zostaje postawiona kwestia podmiotowości - uwikłania jednostki w historię oraz ideologię wraz z jego etycznymi konsekwencjami, a także problem bezpośredniego emocjonalnego zaangażowania w przeszłość zdominowanego przez nieusuwalne poczucie straty. W tej perspektywie przywołana w Bili smo heroi / Hösök voltunk postać jugosłowiańskiego przywódcy to figura czasu przeżytego, gorącego, mocnego. Z kolei młodsi autorzy, tacy jak Jasmina Cibic, starają się koncentrować na treściach uniwersalnych, próbują budować ponadlokalne przesłanie. W omówionych dziełach medium dla ich artykulacji stało się odczytanie biografii architektonicznego obiektu mającego status ikony władzy oraz będącego ekstensją ideologii, a zwłaszcza politycznej siły. Pałac Federacji w bezpośrednio dostępnej dla współczesnego odbiorcy materialnej formie ucieleśnia problematyczne dziedzictwo socjalistycznej federacji, które - jak się wydaje - najsugestywniej przemawia dziś do nas właśnie językiem władzy, a ponieważ jest on instrumentem hierarchizacji, funkcją wywyższenia, co najmocniej akcentują artyści młodszej generacji, trudno więc o familiarną identyfikację, trudno o sentyment, co z kolei wyklucza postawę nostalgiczną (ta wszakże odnosi się do osobistych wspomnień, eksploruje obszary codzienności, popularne rejestry kultury). Pamięć o Jugosławii w tego rodzaju wypowiedziach artystycznych traci nie tylko określoną konotację polityczną i ideologiczną (nie problematyzuje się tematu komunizmu), pozbawiona zostaje także emotywnego potencjału i integracyjno-wspólnotowych znaczeń - ustępują one miejsca badawczemu, dyskursywnemu zainteresowaniu historycznym zjawiskiem i jego estetyką. Natomiast wystawa Szombathyego w takim właśnie kluczu retrospekcji emocjonalnej, choć nie pozbawionej dystansu i krytycyzmu, interpretuje heroizm - autor widzi w nim indywidualną postawę człowieka wobec życia, a zwłaszcza tego, co ono ze sobą przynosi zarówno w wymiarze jednostkowych przekonań i postaw oraz relacji społecznych, jak i w planie Wielkiej Historii. Ekspozycja Bili smo heroi / Hösök voltunk nosi wyraziste znamiona osobistej, intymnej opowieści, bowiem to ona w ostatecznym rozrachunku okazuje się dla węgierskiego twórcy źródłem żywych znaczeń i ostoją sensu.

Wspólną cechą omawianych przedsięwzięć artystycznych jest działanie w przestrzeni i poprzez przestrzeń. Łączy je także refleksja na temat mechanizmów pamięci, jej kondycji w postjugosłowiańskich społeczeństwach, sposobów jej performowania, form wizualizacji oraz technik instrumentalizacji. I choć w centrum artystycznej uwagi usytuowane zostają obiekty (pamiątki, miejsca upamiętnienia, budowle-pomniki), to jednak ostateczna konkluzja za sprawą tak przesłania, jak i stosowanych form podawczych (wystawa - instalacja - film), odpowiadających współczesnej wrażliwości odbirczej, w każdym przypadku jest ta sama. To nie przedmiotowe (fetyszyzujące), lecz symboliczne, komunikacyjne, dyskursywne postrzeganie przeszłości pozwala 
dostrzec w pamięci jakość dynamiczną, semiotycznie otwartą, kreacyjną, która może się konkretyzować w działaniu artystycznym, „naturalizującym“ lub ,denaturalizującym“" porządek symboliczny życia społecznego.

\section{BIBLIOGRAFIA ŹRÓDEŁ I PRAC WYKORZYSTANYCH W TEKŚCIE:}

Albahari David, Mamidto, tłum. Dorota Jovanka Ćirlić, Wydawnictwo W.A.B., Warszawa 2008.

Благојевић Љиљана, Нови Београд. Оспорени модернизам. Стратегије модернизма у планирағу и пројектоваюу урбане структуре и архитектуре Новог Београда, Завод за уџбенике, Архитектонски факултет Универзитета у Београду, Завод за заштиту споменика, Београд 2007.

Bogusławska Magdalena, Egzotyczni przyjaciele Josipa Broza Tity, w: Komunistyczni bohaterowie, t. 1: Tradycja, kult, rytuat, red. Magdalena Bogusławska, Zuzanna Grębecka, Ewa Wróblewska-Trochimiuk, Libron, Warszawa - Kraków 2011.

Bogusławska Magdalena, Obraz władzy we władzy obrazu. Artystyczne konceptualizacje Josipa Broza Tity, Wydział Polonistyki UW - Libron, Warszawa - Kraków 2015.

Đilas Milovan, Druženje s Titom, Harrow, Middlesex 1980.

Mandalian Andrzej, Czerwona orkiestra, Wydawnictwo Sic!, Warszawa 2009.

Šuvaković Miško, Sećanje na umetnost komunizma. Analiza kontradikcija: pristupi i prestupi, „Remont Art Files" 2008-2009, br. 2-3.

Szombathy Bálint, Bili smo heroi / Hösök voltunk [katalog wystawy], http://pl.scribd.com/doc/240135050/ Balint-Szombathy-Bili-smo-heroji-H\%C5\%91 sok-voltunk-KATALOG.

Yates Frances A., Sztuka pamięci, thum. Witold Radwański, Państwowy Instytut Wydawniczy, Warszawa 1977. 